\title{
Analyzing the scheduling system stage of production system life cycle
}

\author{
Rajesh Attri* and Sandeep Grover
}

Department of Mechanical Engineering, YMCA University of Science \& Technology, Faridabad - 121006, India

\begin{tabular}{l}
\hline C H R O N I C L E \\
\hline Article history: \\
Received January 20, 2015 \\
Received in revised format 6 \\
February 2015 \\
Accepted 15 March 2015 \\
Available online \\
March 152015 \\
\hline Keywords: \\
Scheduling system \\
ISM \\
MICMAC \\
Driving power \\
Dependence
\end{tabular}
A B S T R A C T

\begin{abstract}
The main objective of this paper is to identify and understand the relationship dynamics among the quality enabled factors affecting the scheduling stage of production system life cycle. For this purpose, Interpretative structural modelling (ISM) approach has been utilized for developing the relationships among the various factors of the scheduling system stage. Afterwards, MICMAC (Matriced Impacts Croises Multiplication Appliqueeaun Classement) analysis has been carried out in order to classify the factors into different categories and to disclose the direct and indirect effects of each factor on the scheduling system. It is an approach for refining the decision making in the scheduling stage of production system life cycle.
\end{abstract}

\section{Introduction}

The organizational policy offers the frame for making decisions in different operational areas of an organization. The production department of the organization has to frame the decisions or policy with respect to the limits framed by different departments such as quality control \& assurance department, sales \& marketing department, materials and product design department etc. In other words, the production department has to structure the strategic or tactical decisions in concern with other departments. For example, the production department has to produce the product in required amount (limit set by the marketing department) of desired quality (limit set by the quality department). Moreover, these limits changes day by day depending on the requirement. So, in scheduling system stage of the production system life cycle, production mangers have to make their decisions more accurately within the desired time horizon. The details of different stages of the production system life cycle can be found from the literature by Attri and Grover (2012, 2013). In the scheduling stage of the production system life cycle, the production managers have to design the sequence of work in such a way that production can be thoroughly organized to the completion of order by the due date. Kumar and Suresh (2008) have defined the scheduling as "establishing of times at which to begin and complete

\footnotetext{
* Corresponding author.

E-mail address: rajeshattri2005@gmail.com (R. Attri) 
each event or operation comprising a procedure”. The different activities involved in the scheduling system stage of production system life cycle have been tabulated in Table 1.

\section{Table 1}

Key activities of scheduling system stage

\begin{tabular}{|c|c|c|c|}
\hline Stage Name & Activities & \multicolumn{2}{|c|}{ Role of Department } \\
\hline \multirow{10}{*}{$\begin{array}{l}\text { Scheduling } \\
\text { system }\end{array}$} & Design of schedule & \multicolumn{2}{|c|}{ To prepare the schedule depending on the type of the production system } \\
\hline & & Type of production system & Decision support tools \\
\hline & & (a) Project & $\begin{array}{l}\text { Work flow chart, Bar chart, Gantt chart and } \\
\text { Milestone chart }\end{array}$ \\
\hline & & (b) Job & Priority rules \\
\hline & & (c) Batch & Run out method \\
\hline & & (d) Mass production & Line of balance (LOB) method \\
\hline & & (e) Process & $\begin{array}{l}\text { Linear programming simplex algorithm, } \\
\text { queuing theory analysis and simulation } \\
\text { analysis }\end{array}$ \\
\hline & Evaluation of schedule & \multicolumn{2}{|c|}{ Evaluation of schedule as per order } \\
\hline & $\begin{array}{l}\text { Estimation of bottlenecks } \\
\text { in the schedule }\end{array}$ & \multicolumn{2}{|c|}{$\begin{array}{l}\text { Estimation of delay in the schedule as per due date along with the } \\
\text { identification of sources of delay, if any }\end{array}$} \\
\hline & Scheduling bottlenecks & \multicolumn{2}{|c|}{ Rescheduling of delayed orders } \\
\hline
\end{tabular}

The scheduling system necessitates the monitoring of work flows in order to ensure the completion of schedule in the planned time. The decision making in this stage of the production system life cycle is not as easy task because of its inconsistent nature along with the requirement of proper follow-up for each activity of the schedule. Moreover, it is affected by a number of factors known as quality enabled factors such as accurate sequence of order performance, proper dispatching of orders and proper followup of the orders etc. Quality enabled factors are those factors whose consideration will result in better quality decisions. These factors not only influence the scheduling system but also influence each other. The main requirement is to identify and understand the relationship dynamics among the factors. For this purpose, Interpretative structural modelling (ISM) approach has been utilized for developing the relationships among the various factors of the scheduling system.

The main objectives of the current work are (a) to identify the factors affecting the scheduling system (b) to develop the structural model on the basis of their contextual relationships (c) to categorize the factors into different categories (d) to suggest future directions of the current work.

\section{Identification of factors of scheduling system}

The factors affecting the scheduling system stage of production system life cycle are given in Fig. 1.

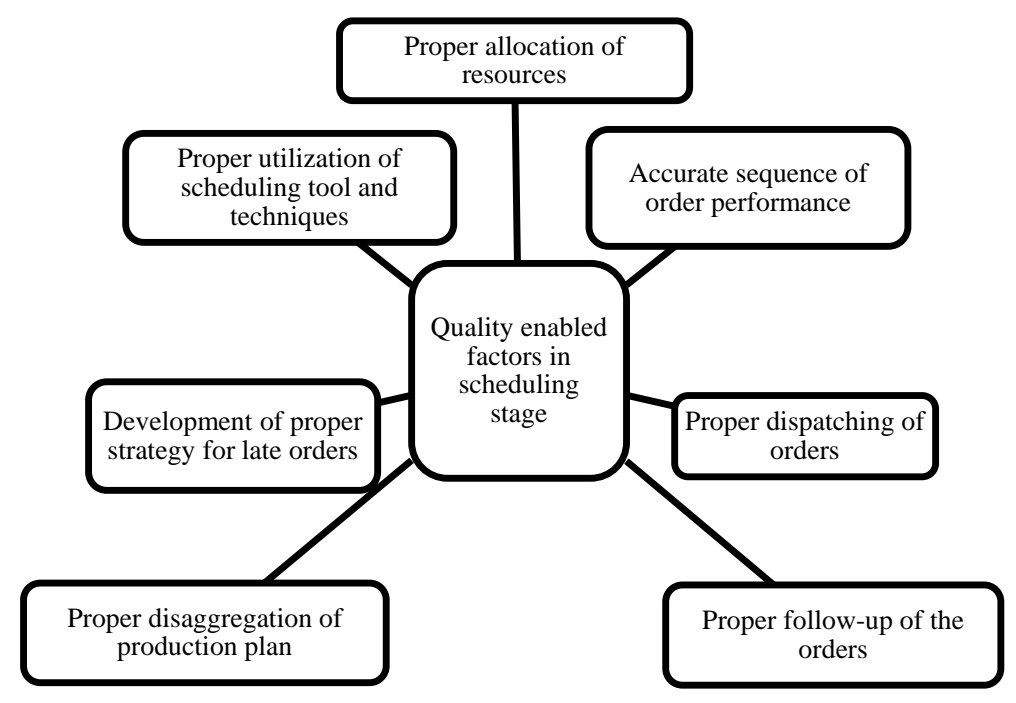

Fig. 1. Quality enabled factors in scheduling system stage 
The details of quality enabled factors are hereby described as follows:

- Proper allocation of resources: In scheduling system specific orders, equipment and work-force are allocated to the work centers or definite localities. Poor allocation of resources can lead to the wastage of resources, late delivery and extra cost for the organization.

- Accurate sequence of order performance: The main objective of scheduling is to design the sequence of order so that production can be thoroughly organized to the completion of order by due date. It is also known as the job priorities.

- Proper dispatching of orders: Dispatching of orders refers to the commencement of performance of planned work. The production department should ensure that the orders are dispatched as per planned schedule.

- Proper follow-up of the orders: The production department must have the proper mechanism for rereading the position of orders during their advancement in production system. It helps in completing the orders in the scheduled time.

- Proper disaggregation of production plan: It is the main tenacity of the scheduling system in which the developed production plan is disaggregated into time phased undertakings such as daily, weekly actions. Production department must accurately translate the production plan into these timely actions.

- Proper utilization of scheduling tool and techniques: Type of scheduling methodology to be used depends upon the type of organization, product and production system. The proper utilization of tool \& techniques in scheduling leads to the accurate allocation of resources to the work-centers. The most commonly used scheduling methodologies are charts and boards (Gantt charts, progress charts, and load charts), priority decision rules, and mathematical programming Methods (linear programming model, PERT/CPM network model).

- Development of proper strategy for late orders: The production department must develop proper strategy for meeting the late orders. In such case, schedule may be revised for meeting the target date. In literature, two rescheduling strategies are available i.e. schedule repair, and complete rescheduling (Sabuncuoglu \& Bayiz, 2000; Cowling \& Johansson, 2002; Vieira et al., 2003). Schedule repair refers to some local adjustment of the current schedule and may be preferable because of the potential saving in CPU times and the stability of the system is preserved. Complete rescheduling regenerates a new schedule from scratch (Ouelhadj \& Petrovic, 2009).

\section{Questionnaire based survey}

\subsection{Instrument development}

The questionnaire was made by using Likart scale (5-point). On this scale, 1 responds to the very low and 5 responds the high importance. The questionnaire was related to the different aspects such as quality enabled factors and barriers of different stages of production system life cycle. But, our paper is related to the quality enabled factors of scheduling system of production system, so we are limited to the factors of this stage only. The respondents were requested to mark the level of importance of these identified factors.

\subsection{Survey administration}

The methods used for the administration of the survey were self-contact and email. The main part of survey was carried out by the personal contact. During survey, engineers, senior engineers, assistant managers and managers were contacted. The survey was carried out in 30 manufacturing organizations. The response rate of the survey administration was $60 \%$, which is quite good enough for carrying out the further analysis. 


\subsection{Respondents’ profile}

(a) In terms of employees: 27\% respondents had less than 100 employees, $13 \%$ had 101-500 employees, 23\% had 501-1000 employees, 10\% had 1001-3000 employees and 27\% had more than 3000 employees.

(b) In terms of annual turnover: $27 \%$ of respondents had up to Rs. 10 crore, $13 \%$ had Rs. 10-50 crore, 23\% had Rs. 50-100 crore, and 37\% had more than Rs. 100 crore.

\subsection{Results of survey}

The questionnaire based survey was carried out in order to find the effect of the identified factors in the scheduling stage of production system life cycle. The statistical analysis of the survey data was carried out as shown in Table 2.

Table 2

Statistics of factors of quality control system stage

\begin{tabular}{lccccc}
\multicolumn{1}{c}{ Factors } & Mean & Median & Mode & $\begin{array}{c}\text { Standard } \\
\text { Deviation }\end{array}$ & Range \\
\hline Proper allocation of resources & & 4.10 & 4 & 4 & 0.712 \\
Accurate sequence of order performance & 4.03 & 4 & 5 & 0.890 & 2 \\
Proper dispatching of orders & 3.97 & 4 & 3 & 0.890 & 2 \\
Proper follow-up of the orders & 4 & 4 & $3^{\text {a }}$ & 0.830 & 2 \\
Proper disaggregation of production plan & 4.07 & 4 & 5 & 0.944 & 3 \\
Proper utilization of scheduling tool and techniques & 3.77 & 3.5 & 3 & 0.858 & 2 \\
Development of proper strategy for late orders & 3.83 & 4 & 4 & 0.874 & 3 \\
\hline
\end{tabular}

Note: ${ }^{a}$ Multiple mode exist. The smallest value is shown.

\section{Interpretive Structural Modelling approach}

Interpretive structural modelling (ISM) approach was developed by Warfield (1974) and Sage (1977). It has been adapted from the paired-comparison approach. ISM is an interactive management tool which transmutes unclear, poorly enunciated mental models of a system into observable well-defined, ordered models (Ahuja et al., 2009; Raj et al., 2012; Attri et al., 2013a; 2013b). ISM approach starts with the identification of elements to be organized (for instance objectives, barriers, factors, enablers, and so on) by the group. The group also identified the nature of relationship between the element such as such as 'causes', 'leads to', 'affects', 'propagates', 'magnifies' and strengthen etc. and so on (Bolaños et al. 2005; Faisal, 2010). ISM approach assists in imposing order and direction of relationships among the identified factors of an issue or problem under consideration (Sage, 1977). This recognized relationship (both direct and indirect) among the factors define the issue more precisely than the single factor. Thus, ISM approach cultivates the better understandings of the relationships between the factors (Singh, 2011). ISM approach has been utilized by the various authors for developing the hierarchical model in different fields of engineering and management. Nath et al. (2013) have modelled the enablers of consumer adoption of green products using the ISM approach. Kumar et al. (2013) have used ISM approach for developing the relationship among the enablers of e-applications in agri-food supply chain. Joshi \& Kant (2012) have applied ISM approach for understanding the dynamics between the various supply chain collaboration enablers. Toktaş-Palut et al. (2014) have applied ISM approach for the empirical analysis of the impact of barriers and benefits of e-procurement on its adoption decision. Cagno et al. (2014) have developed an interpretive model of occupational safety performance for small and medium sized enterprises. Govindan et al. (2014) have analyzed third party reverse logistics provider using the interpretive structural modeling approach.

The various steps involved in ISM approach are itemized in Fig. 2. 


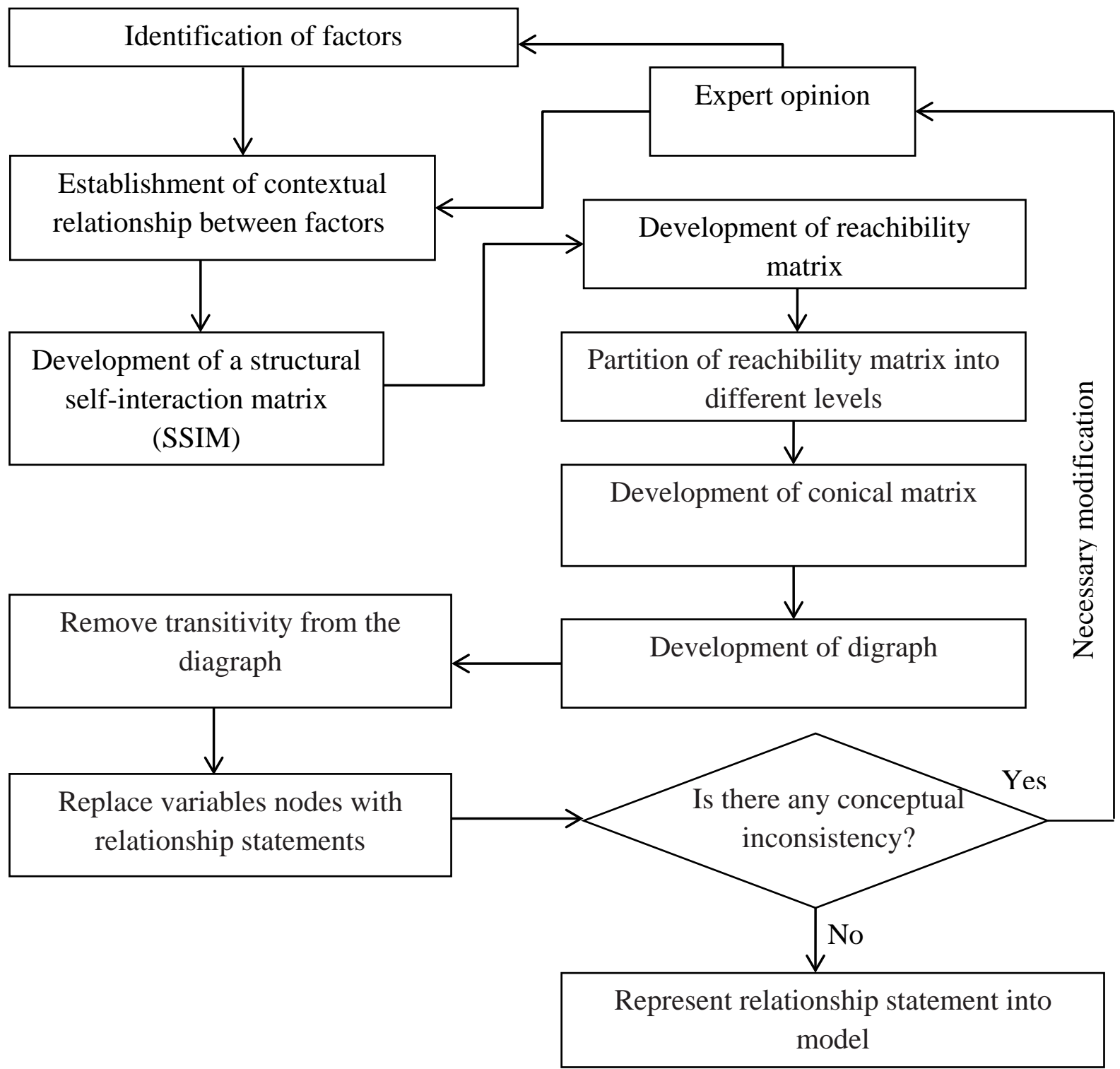

Fig. 2. Flow diagram for preparing ISM model (Raj \& Attri, 2011; Attri et al., 2013c)

For the analysis of the factors of scheduling system stage of production system life cycle following steps were carried out as per steps given in Fig. 2.

\subsection{Identification of factors related to the scheduling system stage}

In the current work, seven factors have been identified with the help of the expert opinion. The experts were from the industrial and academic background having more than 5 years' experience. Following is the list of the factors related to the scheduling system stage of production system life cycle.

Proper allocation of resources

Accurate sequence of order performance

Proper dispatching of orders

Proper follow-up of the orders

Proper disaggregation of production plan

Proper utilization of scheduling tool and techniques

Development of proper strategy for late orders
$F_{1}$

$F_{2}$

$F_{3}$

$F_{4}$

$\mathbf{F}_{5}$

$F_{6}$

$\mathbf{F}_{7}$ 
4.2 Establishment of contextual relationship between factors and development of Structural selfinteractive matrix (SSIM)

In this step of ISM approach, 'leads to' type contextual relationship has been taken for recognizing the relationship among the identified factors (done in earlier step). Here, experts (same group of experts used for identifying factors) were again approached for identifying the nature of relationship between the factors along with their associated direction. For this purpose, following four symbols (More \& Basu, 2013) were used for indicating the relationship between any two factors ( $\mathrm{i}$ and $\mathrm{j}$ ):

- FR: Factor i influences Factor j (Forward relationship);

- BR: Factor j influences Factor i (Backward relationship);

- $\quad$ CR: Factor i and j influences each other (Cross relationship); and

- $\quad$ NO: Factor i and j does not influences each other (No relationship).

On the basis of the identified contextual relationship by the group of experts, Structural self-interactive matrix (SSIM) was developed (Table 3).

Table 3

Structural self-interactive matrix (SSIM)

\begin{tabular}{|c|c|c|c|c|c|c|c|c|}
\hline Factors & & $\mathbf{F}_{7}$ & $\mathbf{F}_{6}$ & $\mathbf{F}_{5}$ & $\mathbf{F}_{4}$ & $\mathbf{F}_{3}$ & $\mathbf{F}_{2}$ & $\mathbf{F}_{1}$ \\
\hline Proper allocation of resources & $\mathbf{F}_{1}$ & FR & FR & BR & FR & FR & CR & \\
\hline Accurate sequence of order performance & $\mathbf{F}_{2}$ & FR & FR & $\mathrm{BR}$ & FR & FR & & \\
\hline Proper dispatching of orders & $\mathbf{F}_{3}$ & FR & FR & $\mathrm{BR}$ & FR & & & \\
\hline Proper follow-up of the orders & $\mathbf{F}_{4}$ & FR & $\mathrm{BR}$ & BR & & & & \\
\hline Proper disaggregation of production plan & $\mathbf{F}_{5}$ & FR & FR & & & & & \\
\hline $\begin{array}{l}\text { Proper utilization of scheduling tool and } \\
\text { techniques }\end{array}$ & $\mathbf{F}_{6}$ & FR & & & & & & \\
\hline $\begin{array}{l}\text { Development of proper strategy for late } \\
\text { orders }\end{array}$ & $\mathbf{F}_{7}$ & & & & & & & \\
\hline
\end{tabular}

\subsection{Development of reachability matrix}

In this step of ISM approach, initial and final reachability matrix is developed. Initial matrix is developed by transforming the SSIM into binary matrix. It is carried out by substituting the binary digits i.e. 0 and 1 in place of SSIM symbols i.e. FR, BR, CR, NO. For this purpose, following rules were utilized (More \& Basu, 2013):

- If the entry of cell ( $i$ and $j$ ) in the SSIM is FR, then cell ( $i$ and $j$ ) is assigned 1 value and cell ( $j$ and $i)$ is assigned 0 value.

- If the entry of cell ( $i$ and $j$ ) in the SSIM is BR, then cell ( $i$ and $j$ ) is assigned 0 value and cell ( $j$ and $i)$ is assigned 1 value.

- If the entry of cell ( $i$ and $j$ ) in the SSIM is CR, then cell ( $i$ and $j$ ) is assigned 1 value and cell ( $j$ and $i)$ is assigned 1 value.

- If the entry of cell ( $i$ and $j$ ) in the SSIM is NO, then cell ( $i$ and $j$ ) is assigned 0 value and cell ( $j$ and $i$ ) is assigned 0 value.

On following the above mentioned rules, initial reachability matrix is developed (Table 4). After the formation of initial reachability matrix, final reachability matrix is developed. This matrix is formulated by the introduction of transitivity concept in the initial reachability matrix. Transitivity is the basic assumption of the ISM methodology. It specifies that if factor A influences factor B and factor B influences another factor $\mathrm{C}$, then factor $\mathrm{A}$ will also influence factor $\mathrm{C}$. The developed final reachability matrix is presented in Table 5. 
Table 4

Initial reachability matrix

\begin{tabular}{cccccccc}
\hline Factors & $\mathbf{F}_{\mathbf{1}}$ & $\mathbf{F}_{\mathbf{2}}$ & $\mathbf{F}_{\mathbf{3}}$ & $\mathbf{F}_{\mathbf{4}}$ & $\mathbf{F}_{\mathbf{5}}$ & $\mathbf{F}_{\mathbf{6}}$ & $\mathbf{F}_{\mathbf{7}}$ \\
\hline $\mathbf{F}_{\mathbf{1}}$ & 1 & 1 & 1 & 1 & 0 & 1 & 1 \\
$\mathbf{F}_{\mathbf{2}}$ & 1 & 1 & 1 & 1 & 0 & 1 & 1 \\
$\mathbf{F}_{\mathbf{3}}$ & 0 & 0 & 1 & 1 & 0 & 1 & 1 \\
$\mathbf{F}_{\mathbf{4}}$ & 0 & 0 & 0 & 1 & 0 & 0 & 1 \\
$\mathbf{F}_{\mathbf{5}}$ & 1 & 1 & 1 & 1 & 1 & 1 & 1 \\
$\mathbf{F}_{\mathbf{6}}$ & 0 & 0 & 0 & 1 & 0 & 1 & 1 \\
$\mathbf{F}_{\mathbf{7}}$ & 0 & 0 & 0 & 0 & 0 & 0 & 1 \\
\hline
\end{tabular}

Table 5

Final reachability matrix

\begin{tabular}{cccccccc}
\hline Factors & $\mathbf{F}_{\mathbf{1}}$ & $\mathbf{F}_{\mathbf{2}}$ & $\mathbf{F}_{\mathbf{3}}$ & $\mathbf{F}_{\mathbf{4}}$ & $\mathbf{F}_{\mathbf{5}}$ & $\mathbf{F}_{\mathbf{6}}$ & $\mathbf{F}_{\mathbf{7}}$ \\
\hline $\mathbf{F}_{\mathbf{1}}$ & 1 & 1 & 1 & 1 & 0 & 1 & 1 \\
$\mathbf{F}_{\mathbf{2}}$ & 1 & 1 & 1 & 1 & 0 & 1 & 1 \\
$\mathbf{F}_{\mathbf{3}}$ & 0 & 0 & 1 & 1 & 0 & 1 & 1 \\
$\mathbf{F}_{\mathbf{4}}$ & 0 & 0 & 0 & 1 & 0 & 0 & 1 \\
$\mathbf{F}_{\mathbf{5}}$ & 1 & 1 & 1 & 1 & 1 & 1 & 1 \\
$\mathbf{F}_{\mathbf{6}}$ & 0 & 0 & 0 & 1 & 0 & 1 & 1 \\
$\mathbf{F}_{\mathbf{7}}$ & 0 & 0 & 0 & 0 & 0 & 0 & 1 \\
\hline
\end{tabular}

It may be noted here, that the Table 4 and 5 are same as there is no scope of transitivity in the initial reachability matrix.

\subsection{Partition of reachability matrix}

In this step, final reachability matrix is partitioned into different levels. These identified levels of the factors help in the development of the digraph and ISM model. It is carried out by identifying the reachability set, antecedent set and intersection set for each factor from the final reachability matrix. Reachability set of a factor consists of those factors which influences by this factor along with itself and antecedent set of a factor consists of those factors which will influence this factor along with itself. Intersection set of a factor is identified by finding the common of the reachability set and antecedent set of that factor. The factors for which reachability set and antecedent set are same will be termed as top level factors. These factors will occupy the top level in the digraph as well as in the ISM model. After, the identification of top level factors, these factors is removed from the other factors. Then same procedure is continued to find the factors at the next level. Same procedure is repeated till all the factors have been identified with their specific levels. The steps or iterations carried for identifying the specific level of each factors are presented in Tables 6-11.

Table 6

Iteration 1

\begin{tabular}{cllll}
\hline $\begin{array}{c}\text { Factors } \\
\left(\mathbf{F}_{\mathbf{i}}\right)\end{array}$ & $\begin{array}{l}\text { Reachability set } \\
\mathbf{R}\left(\mathbf{F}_{\mathbf{i}}\right)\end{array}$ & $\begin{array}{l}\text { Antecedent set } \\
\mathbf{A}\left(\mathbf{F}_{\mathbf{i}}\right)\end{array}$ & $\begin{array}{l}\text { Intersection set } \\
\mathbf{R}\left(\mathbf{F}_{\mathbf{i}}\right) \cap \mathbf{A}\left(\mathbf{F}_{\mathbf{i}}\right)\end{array}$ & Level \\
\hline $\mathbf{F}_{\mathbf{1}}$ & $\mathrm{F}_{1}, \mathrm{~F}_{2}, \mathrm{~F}_{3}, \mathrm{~F}_{4}, \mathrm{~F}_{6}, \mathrm{~F}_{7}$ & $\mathrm{~F}_{1}, \mathrm{~F}_{2}, \mathrm{~F}_{5}$ & $\mathrm{~F}_{1}, \mathrm{~F}_{2}$ \\
$\mathbf{F}_{\mathbf{2}}$ & $\mathrm{F}_{1}, \mathrm{~F}_{2}, \mathrm{~F}_{3}, \mathrm{~F}_{4}, \mathrm{~F}_{6}, \mathrm{~F}_{7}$ & $\mathrm{~F}_{1}, \mathrm{~F}_{2}, \mathrm{~F}_{5}$ & $\mathrm{~F}_{1}, \mathrm{~F}_{2}$ \\
$\mathbf{F}_{3}$ & $\mathrm{~F}_{3}, \mathrm{~F}_{4}, \mathrm{~F}_{6}, \mathrm{~F}_{7}$ & $\mathrm{~F}_{1}, \mathrm{~F}_{2}, \mathrm{~F}_{3}, \mathrm{~F}_{5}$ & $\mathrm{~F}_{3}$ \\
$\mathbf{F}_{\mathbf{4}}$ & $\mathrm{F}_{4}, \mathrm{~F}_{7}$ & $\mathrm{~F}_{1}, \mathrm{~F}_{2}, \mathrm{~F}_{3}, \mathrm{~F}_{4}, \mathrm{~F}_{5}, \mathrm{~F}_{6}$ & $\mathrm{~F}_{4}$ \\
$\mathbf{F}_{5}$ & $\mathrm{~F}_{1}, \mathrm{~F}_{2}, \mathrm{~F}_{3}, \mathrm{~F}_{4}, \mathrm{~F}_{5}, \mathrm{~F}_{6}, \mathrm{~F}_{7}$ & $\mathrm{~F}_{5}$ & $\mathrm{~F}_{5}$ \\
$\mathbf{F}_{\mathbf{6}}$ & $\mathrm{F}_{4}, \mathrm{~F}_{6}, \mathrm{~F}_{7}$ & $\mathrm{~F}_{1}, \mathrm{~F}_{2}, \mathrm{~F}_{3}, \mathrm{~F}_{5}, \mathrm{~F}_{6}$ & $\mathrm{~F}_{6}$ \\
$\mathbf{F}_{7}$ & $\mathrm{~F}_{7}$ & $\mathrm{~F}_{1}, \mathrm{~F}_{2}, \mathrm{~F}_{3}, \mathrm{~F}_{4}, \mathrm{~F}_{5}, \mathrm{~F}_{6}, \mathrm{~F}_{7}$ & $\mathrm{~F}_{7}$ & \\
\hline
\end{tabular}


Table 7

Iteration 2

\begin{tabular}{cllll}
\hline $\begin{array}{c}\text { Factors } \\
\left(\mathbf{F}_{\mathbf{i}}\right)\end{array}$ & $\begin{array}{l}\text { Reachability set } \\
\mathbf{R}\left(\mathbf{F}_{\mathbf{i}}\right)\end{array}$ & $\begin{array}{l}\text { Antecedent set } \\
\mathbf{A}\left(\mathbf{F}_{\mathbf{i}}\right)\end{array}$ & $\begin{array}{l}\text { Intersection set } \\
\mathbf{R}\left(\mathbf{F}_{\mathbf{i}}\right) \cap \mathbf{A}\left(\mathbf{F}_{\mathbf{i}}\right)\end{array}$ & Level \\
\hline $\mathbf{F}_{\mathbf{1}}$ & $\mathrm{F}_{1}, \mathrm{~F}_{2}, \mathrm{~F}_{3}, \mathrm{~F}_{4}, \mathrm{~F}_{6}$ & $\mathrm{~F}_{1}, \mathrm{~F}_{2}, \mathrm{~F}_{5}$ & $\mathrm{~F}_{1}, \mathrm{~F}_{2}$ & \\
$\mathbf{F}_{2}$ & $\mathrm{~F}_{1}, \mathrm{~F}_{2}, \mathrm{~F}_{3}, \mathrm{~F}_{4}, \mathrm{~F}_{6}$ & $\mathrm{~F}_{1}, \mathrm{~F}_{2}, \mathrm{~F}_{5}$ & $\mathrm{~F}_{1}, \mathrm{~F}_{2}$ & \\
$\mathbf{F}_{3}$ & $\mathrm{~F}_{3}, \mathrm{~F}_{4}, \mathrm{~F}_{6}$ & $\mathrm{~F}_{1}, \mathrm{~F}_{2}, \mathrm{~F}_{3}, \mathrm{~F}_{5}$ & $\mathrm{~F}_{3}$ & \\
$\mathbf{F}_{4}$ & $\mathrm{~F}_{4}$ & $\mathrm{~F}_{1}, \mathrm{~F}_{2}, \mathrm{~F}_{3}, \mathrm{~F}_{4}, \mathrm{~F}_{5}, \mathrm{~F}_{6}$ & $\mathrm{~F}_{4}$ & II \\
$\mathbf{F}_{5}$ & $\mathrm{~F}_{1}, \mathrm{~F}_{2}, \mathrm{~F}_{3}, \mathrm{~F}_{4}, \mathrm{~F}_{5}, \mathrm{~F}_{6}$ & $\mathrm{~F}_{5}, \mathrm{~F}_{5}$ & \\
$\mathbf{F}_{\mathbf{6}}$ & $\mathrm{F}_{4}, \mathrm{~F}_{6}$ & $\mathrm{~F}_{1}, \mathrm{~F}_{2}, \mathrm{~F}_{3}, \mathrm{~F}_{5}, \mathrm{~F}_{6}$ & $\mathrm{~F}_{6}$ & \\
\hline
\end{tabular}

Table 8

Iteration 3

\begin{tabular}{cllll}
\hline $\begin{array}{c}\text { Factors } \\
\left(\mathbf{F}_{\mathbf{i}}\right)\end{array}$ & $\begin{array}{l}\text { Reachability set } \\
\mathbf{R}\left(\mathbf{F}_{\mathbf{i}}\right)\end{array}$ & $\begin{array}{l}\text { Antecedent set } \\
\mathbf{A}\left(\mathbf{F}_{\mathbf{i}}\right)\end{array}$ & $\begin{array}{l}\text { Intersection set } \\
\mathbf{R}\left(\mathbf{F}_{\mathbf{i}}\right) \cap \mathbf{A}\left(\mathbf{F}_{\mathbf{i}}\right)\end{array}$ & Level \\
\hline $\mathbf{F}_{\mathbf{1}}$ & $\mathrm{F}_{1}, \mathrm{~F}_{2}, \mathrm{~F}_{3}, \mathrm{~F}_{6}$ & $\mathrm{~F}_{1}, \mathrm{~F}_{2}, \mathrm{~F}_{5}$ & $\mathrm{~F}_{1}, \mathrm{~F}_{2}$ & \\
$\mathbf{F}_{2}$ & $\mathrm{~F}_{1}, \mathrm{~F}_{2}, \mathrm{~F}_{3}, \mathrm{~F}_{6}$ & $\mathrm{~F}_{1}, \mathrm{~F}_{2}, \mathrm{~F}_{5}$ & $\mathrm{~F}_{1}, \mathrm{~F}_{2}$ & \\
$\mathbf{F}_{3}$ & $\mathrm{~F}_{3}, \mathrm{~F}_{6}$ & $\mathrm{~F}_{1}, \mathrm{~F}_{2}, \mathrm{~F}_{3}, \mathrm{~F}_{5}$ & $\mathrm{~F}_{3}$ & \\
$\mathbf{F}_{5}$ & $\mathrm{~F}_{1}, \mathrm{~F}_{2}, \mathrm{~F}_{3}, \mathrm{~F}_{5}, \mathrm{~F}_{6}$ & $\mathrm{~F}_{5}$ & $\mathrm{~F}_{5}$ & \\
$\mathbf{F}_{\mathbf{6}}$ & $\mathrm{F}_{4}$ & $\mathrm{~F}_{1}, \mathrm{~F}_{2}, \mathrm{~F}_{3}, \mathrm{~F}_{5}, \mathrm{~F}_{6}$ & $\mathrm{~F}_{6}$ & III \\
\hline
\end{tabular}

Table 9

Iteration 4

\begin{tabular}{cllll}
\hline $\begin{array}{c}\text { Factors } \\
\left(\mathbf{F}_{\mathbf{i}}\right)\end{array}$ & $\begin{array}{l}\text { Reachability set } \\
\mathbf{R}\left(\mathbf{F}_{\mathbf{i}}\right)\end{array}$ & $\begin{array}{l}\text { Antecedent set } \\
\mathbf{A}\left(\mathbf{F}_{\mathbf{i}}\right)\end{array}$ & $\begin{array}{l}\text { Intersection set } \\
\mathbf{R}\left(\mathbf{F}_{\mathbf{i}}\right) \cap \mathbf{A}\left(\mathbf{F}_{\mathbf{i}}\right)\end{array}$ & Level \\
\hline $\mathbf{F}_{\mathbf{1}}$ & $\mathrm{F}_{1}, \mathrm{~F}_{2}, \mathrm{~F}_{3}$ & $\mathrm{~F}_{1}, \mathrm{~F}_{2}, \mathrm{~F}_{5}$ & $\mathrm{~F}_{1}, \mathrm{~F}_{2}$ & \\
$\mathbf{F}_{2}$ & $\mathrm{~F}_{1}, \mathrm{~F}_{2}, \mathrm{~F}_{3}$ & $\mathrm{~F}_{1}, \mathrm{~F}_{2}, \mathrm{~F}_{5}$ & $\mathrm{~F}_{1}, \mathrm{~F}_{2}$ & \\
$\mathbf{F}_{3}$ & $\mathrm{~F}_{3}$ & $\mathrm{~F}_{1}, \mathrm{~F}_{2}, \mathrm{~F}_{3}, \mathrm{~F}_{5}$ & $\mathrm{~F}_{3}$ & IV \\
$\mathbf{F}_{5}$ & $\mathrm{~F}_{1}, \mathrm{~F}_{2}, \mathrm{~F}_{3}, \mathrm{~F}_{5}$ & $\mathrm{~F}_{5}$ & $\mathrm{~F}_{5}$ & \\
\hline
\end{tabular}

Table 10

Iteration 5

\begin{tabular}{cllll}
\hline $\begin{array}{c}\text { Factors } \\
\left(\mathbf{F}_{\mathbf{i}}\right)\end{array}$ & $\begin{array}{l}\text { Reachability set } \\
\mathbf{R}\left(\mathbf{F}_{\mathbf{i}}\right)\end{array}$ & $\begin{array}{l}\text { Antecedent set } \\
\mathbf{A}\left(\mathbf{F}_{\mathbf{i}}\right)\end{array}$ & $\begin{array}{l}\text { Intersection set } \\
\mathbf{R}\left(\mathbf{F}_{\mathbf{i}}\right) \cap \mathbf{A}\left(\mathbf{F}_{\mathbf{i}}\right)\end{array}$ & Level \\
\hline $\mathbf{F}_{\mathbf{1}}$ & $\mathrm{F}_{1}, \mathrm{~F}_{2}$ & $\mathrm{~F}_{1}, \mathrm{~F}_{2}, \mathrm{~F}_{5}$ & $\mathrm{~F}_{1}, \mathrm{~F}_{2}$ & $\mathbf{V}$ \\
\hline $\mathbf{F}_{2}$ & $\mathrm{~F}_{1}, \mathrm{~F}_{2}$ & $\mathrm{~F}_{1}, \mathrm{~F}_{2}, \mathrm{~F}_{5}$ & $\mathrm{~F}_{1}, \mathrm{~F}_{2}$ & $\mathbf{V}$ \\
$\mathbf{F}_{5}$ & $\mathrm{~F}_{1}, \mathrm{~F}_{2}, \mathrm{~F}_{5}$ & $\mathrm{~F}_{5}$ & $\mathrm{~F}_{5}$ & \\
\hline
\end{tabular}

Table 11

Iteration 6

\begin{tabular}{cllll}
\hline $\begin{array}{c}\text { Factors } \\
\left(\mathbf{F}_{\mathbf{i}}\right)\end{array}$ & $\begin{array}{l}\text { Reachability set } \\
\mathbf{R}\left(\mathbf{F}_{\mathbf{i}}\right)\end{array}$ & $\begin{array}{l}\text { Antecedent set } \\
\mathbf{A}\left(\mathbf{F}_{\mathbf{i}}\right)\end{array}$ & $\begin{array}{l}\text { Intersection set } \\
\mathbf{R}\left(\mathbf{F}_{\mathbf{i}}\right) \cap \mathbf{A}\left(\mathbf{F}_{\mathbf{i}}\right)\end{array}$ & Level \\
\hline $\mathbf{F}_{5}$ & $\mathrm{~F}_{5}$ & $\mathrm{~F}_{5}$ & $\mathrm{~F}_{5}$ & $\mathbf{V I}$ \\
\hline
\end{tabular}

\subsection{Development of conical matrix}

In this step, the final reachability matrix is converted into its conical form, i.e., with most ' 0 ' elements in the upper half diagonal and most ' 1 ' elements in the lower half diagonal of the matrix (Table 12). It is done by rearranging the final reachability matrix as per the identified levels in the partitioning step of ISM approach. In the conical matrix (Table 12), the driving power and dependence power of each factor is also computed. Driving power for a factor is the total number of factors that is influencing that 
factor (i.e. total number of 1s column wise). Dependence power of a factor is the total number of factors that is being influenced by that factor (i.e. total number of 1s column wise). On the basis of driving and dependence power, the factors are also ranked (Table 12).

\section{Table 12}

Conical Matrix

\begin{tabular}{|c|c|c|c|c|c|c|c|c|c|}
\hline Factors & $\mathbf{F}_{7}$ & $\mathbf{F}_{4}$ & $\mathbf{F}_{6}$ & $\mathbf{F}_{3}$ & $\mathbf{F}_{1}$ & $\mathbf{F}_{2}$ & $\mathbf{F}_{5}$ & Drive Power & Rank \\
\hline $\mathbf{F}_{7}$ & 1 & 0 & 0 & 0 & 0 & 0 & 0 & 1 & VI \\
\hline $\mathbf{F}_{4}$ & 1 & 1 & 0 & 0 & 0 & 0 & 0 & 2 & $\mathbf{V}$ \\
\hline $\mathbf{F}_{6}$ & 1 & 1 & 1 & 0 & 0 & 0 & 0 & 3 & IV \\
\hline $\mathbf{F}_{3}$ & 1 & 1 & 1 & 1 & 0 & 0 & 0 & 4 & III \\
\hline $\mathbf{F}_{1}$ & 1 & 1 & 1 & 1 & 1 & 1 & 0 & 6 & II \\
\hline $\mathbf{F}_{2}$ & 1 & 1 & 1 & 1 & 1 & 1 & 0 & 6 & II \\
\hline $\mathbf{F}_{5}$ & 1 & 1 & 1 & 1 & 1 & 1 & 1 & 7 & I \\
\hline Dependence Power & 7 & 6 & 5 & 4 & 3 & 3 & 1 & & \\
\hline Rank & I & II & III & IV & $\mathbf{V}$ & $\mathbf{V}$ & VI & & \\
\hline
\end{tabular}

\subsection{Development of digraph}

Digraph (directed graph) is developed (Figure 3) from the conical matrix (Table 12) after removing the transitive links. In the digraph, top level factors will occupy the top level, second level factor will occupy the second level and so on, till the lowest level factor is located at the lowest level of digraph.

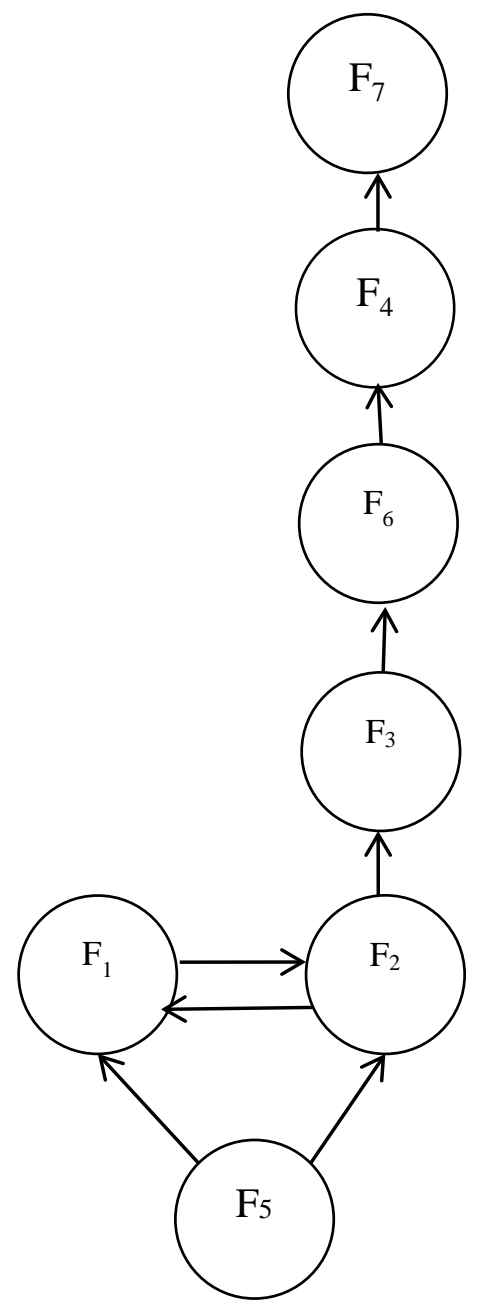

Fig. 3. Digraph showing levels of factors

\subsection{Development of ISM model}

In this step of ISM approach, ISM model (Fig. 4) is developed from the digraph by changing factor nodes with statements. Fig. 4 shows the specific order and direction of the relationship among the factors under consideration. 


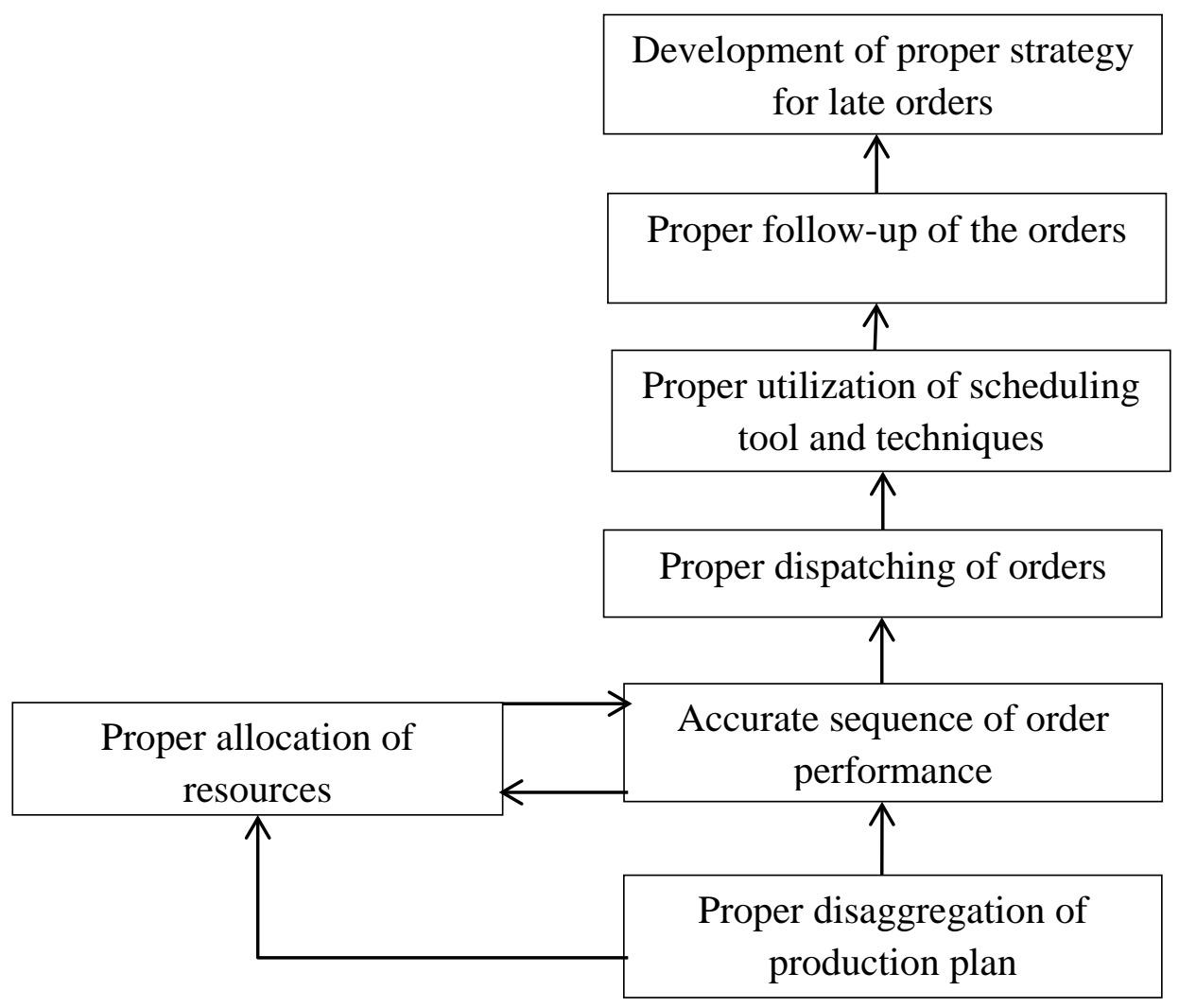

Fig. 4. Interpretive structural model showing levels of factors

\subsection{Check for conceptual inconsistency}

At last, the developed ISM model (Fig. 4) is verified for conceptual inconsistency and required modifications are carried out.

\section{MICMAC analysis}

MICMAC was developed by Duperrin \& Godet (1973). MICMAC stands for Matrice d'Impacts croises-multipication applique' a classment (cross-impact matrix multiplication applied to classification). The main purpose of MICMAC analysis is to analyze the driving power and dependence of factors. MICMAC analysis is performed to classify the previously recognized factors into different categories (Fig. 5) as follows:

- Autonomous factors: Factors in this category have weak drive power and weak dependence.

- Linkage factors: Factors in this category have strong drive power and strong dependence.

- Dependent factors: Factors in this category have weak drive power and strong dependence.

- Independent factors: Factors in this category have strong drive power and weak dependence. Driving Power

\begin{tabular}{|c|c|c|c|c|c|c|c|}
\hline $\mathbf{7}$ & $\mathrm{F}_{5}$ & & & & & & \\
\hline $\mathbf{6}$ & & IV & $\mathrm{F}_{1}, \mathrm{~F}_{2}$ & & III & & \\
\hline $\mathbf{5}$ & & & & & & & \\
\hline $\mathbf{4}$ & & & & $\mathrm{F}_{3}$ & & & \\
\hline $\mathbf{3}$ & & & & & $\mathrm{F}_{6}$ & & \\
\hline $\mathbf{2}$ & & $\mathrm{I}$ & & & II & $\mathrm{F}_{4}$ & \\
\hline $\mathbf{1}$ & & & & & & & $\mathrm{F}_{7}$ \\
\hline & $\mathbf{1}$ & $\mathbf{2}$ & $\mathbf{3}$ & $\mathbf{4}$ & $\mathbf{5}$ & $\mathbf{6}$ & $\mathbf{7}$ \\
\hline
\end{tabular}

\section{Dependence power}

Fig. 5. Driving power-dependence diagram 
It may be noted autonomous factors lies in first quadrant, dependent factors lies in second quadrant, linkage factors lies in third quadrant and independent factors lies in forth quadrant of driving powerdependence diagram (Fig. 5).

\section{Conclusion \& Discussion}

Scheduling is a main part of the operational phase of the production system. It involves the allocation of resources to execute a particular job within the specified time. In this paper, an effort has been made to recognize the factors affecting the scheduling system stage of production system life cycle. Although a lot of literature has been devoted for solving various types of scheduling problems but no study is available on the identification and analysis of factors affecting the scheduling system. So, these factors have been modelled in order to develop a model for understanding of their relation dynamics. The present developed model will help the practicing manufacturing managers to understand the relationship crux of these factors.

Moreover, this paper has major implications for the practicing manufacturing managers. The driver power-dependence matrix (Fig. 5) provides some valued perceptions about the relative importance and interdependencies among the factors. The managerial implications evolving from this paper are as follows:

- The driver power-dependence matrix (Fig. 5) specifies that there is no autonomous factor.

- Factors such as development of proper strategy for late orders, proper follow-up of the orders and proper utilization of scheduling tool and techniques possess weak driving power and strong dependence on other factors. These factors occupy top level in the ISM model.

- There is only one linkage factor i.e. proper dispatching of orders. This factor is having strong driving power as well as strong dependence.

- Driver power dependence diagram also shows that factors such as proper allocation of resources, accurate sequence of order performance and proper disaggregation of production plan are independent factors. These factors possess strong driving power and weak dependence. Moreover, these factors are located at the bottom level of the ISM hierarchy. Furthermore, these factors are known as key factors. The manufacturing managers should devise proper strategies for these factors.

MICMAC analysis depicts that the manufacturing managers should disaggregate the production plan appropriately along with the proper allocation of resources and accurate sequence of order performance in order to have better decisions in scheduling stage of production system life cycle. It may be noted here that this developed ISM model is not statistically validated. For this purpose, structural equation modelling approach (SEM) may be utilized. SEM approach has the capability of testing the validity of such hypothetical models.

\section{References}

Ahuja, V., Yang, J. \& Shankar, R. (2009). Benefits of collaborative ICT adoption for building project management. Construction Innovation, 9(3), 323-340.

Attri, R. \& Grover, S. (2013). Production system life cycle: An Inside story. Accepted in International Journal of Industrial and Systems Engineering.

Attri, R. \& Grover, S., (2012). A comparison of production system life cycle models. Frontiers of Mechanical Engineering, 7(3), 305-311.

Attri, R., Grover, S., Dev, N. \& Kumar, D. (2013a). An ISM approach for modelling the enablers in the implementation of Total Productive Maintenance (TPM). International Journal of Systems Assurance Engineering and Management, 4(4), 313-326.

Attri, R., Grover, S., Dev, N. \& Kumar, D. (2013b). Analysis of barriers of Total Productive Maintenance (TPM). International Journal of Systems Assurance Engineering and Management, 4(4), 365-377. 
Attri, R., Dev, N. \& Sharma, V. (2013c). Interpretive Structural Modelling (ISM) approach: An Overview. Research Journal of Management Sciences, 2(2), 3-8.

Bolanos, R., Fontela, E., Nenclares, A. \& Pastor, P. (2005). Using interpretive structural modelling in strategic decision-making groups. Management Decision, 43(6), 877-895.

Cagno, E., Micheli, G. J. L., Jacinto, C. \& Masi, D. (2014). An interpretive model of occupational safety performance for Small- and Medium-sized Enterprises. International Journal of Industrial Ergonomics, 44, 60-74.

Cowling, P. I., and Johansson, M. (2002). Using real-time information for effective dynamic scheduling. European Journal of Operational Research, 139(2), 230-244.

Duperrin, J. C. \& Godet, M. (1973). Methode De Hierar Chization Des Elements D’um System. Rapport Economique De CEA, R-45-51, Paris.

Faisal, M. N. (2010). Analysing the barriers to corporate social responsibility in supply chains: an interpretive structural modelling approach. International Journal of Logistics: Research and Applications, 13(3), 179-195

Govindan, K., Palaniappan, M., Zhu, Q. \& Kannan, D. (2014). Analysis of third party reverse logistics provider using interpretive structural modelling. International Journal of Production Economics, 140, 204-211.

Haleem, A., Sushil, Qadri, M. A. \& Kumar, S. (2012). Analysis of critical success factors of worldclass manufacturing practices: an application of interpretative structural modelling and interpretative ranking process. Production Planning \& Control, 23(10-11), 722-734.

Joshi, K. \& Kant, R. (2012). Structuring the underlying relations among the enablers of supply chain collaboration. International Journal of Collaborative Enterprise, 3(1), 38-59.

Kumar, R., Agrawal, R. \& Sharma, V. (2013). E-Applications in Indian Agri-Food Supply Chain: Relationship among Enablers. Global business review, 14(4), 711-727.

Kumar, S. A. \& Suresh, N. (2008). Production and Operations Management. New Age International (P) Ltd., Publishers, New Delhi.

More, D. \& Basu, P. (2013). Challenges of supply chain finance: A detailed study and a hierarchical model based on the experiences of an Indian firm. Business Process Management Journal, 19(4), 624-647.

Nath, V., Kumar, R., Agrawal, R., Gautam, A. \& Sharma, V. (2013). Consumer Adoption of Green Products: Modelling the enablers. Global business review, 14(3), 453-470.

Ouelhadj, D. \& Petrovic, S. (2009). A survey of dynamic scheduling in manufacturing systems. Journal of Scheduling, 12(4), 417-431.

Raj, T. \& Attri, R. (2011). Identification and modelling of barriers in the implementation of TQM. International Journal of Productivity and Quality Management, 8(2), 153-179.

Raj, T., Attri, R. \& Jain, V. (2012). Modelling the factors affecting flexibility in FMS. International Journal of Industrial and System Engineering, 11(4), 350-374.

Sabuncuoglu, I., \& Bayiz, M. (2000). Analysis of reactive scheduling problems in a job shop environment. European Journal of Operational Research, 126(3), 567-586.

Sage, A. P. (1977). Interpretive Structural Modelling: Methodology for Large Scale Systems. McGrawHill, New York, NY, 91-164.

Singh, R. K. (2011). Developing the framework for coordination in supply chain of SMEs. Business Process Management Journal, 17(4), 619-638.

Toktaş-Palut, Baylav, E., Teoman, S. \& Altunbey, M. (2014). The impact of barriers and benefits of eprocurement on its adoption decision: An empirical analysis. International Journal of Production Economics, 158, 77-90.

Vieira, G. E., Hermann, J. W., \& Lin, E. (2003). Rescheduling manufacturing systems: a framework of strategies, policies and methods. Journal of Scheduling, 6(1), 39-62.

Warfield, J. N. (1974). Developing interconnection matrices in structural modelling. IEEE Transactions on Systems Man and Cybernetics, 4(1), 81-87. 